\title{
Re: Fibrin Glue Injections: A Minimally Invasive and Cost-Effective Treatment for Post-Renal Transplant Lymphoceles and Lymph Fistulas
}

\author{
Presser N, Kerr H, Gao T, Begala M, Paschal S, Shoskes DA, Flechner SM \\ Cleveland Clinic Foundation, Glickman Urological and Kidney Institute, Renal Transplant Program, Cleveland, $\mathrm{OH}$
}

Am J Transplant. 2016;16:694-699. doi: 10.1111/ajt.13470. Epub 2015 Oct 13.

\section{EDITORIAL COMMENT}

In this retrospective study, 46 (2.7\%) patients out of 1662 kidney transplant recipients had developed symptomatic lymphocele/lymph fistula requiring intervention over an 11-year period. Open surgical drainage (22), laparoscopic surgical drainage (11) and percutaneous fibrin glue injections into the drained lymphocele cavity (13) were used to treat this complication.

Besides being effective both on the early and late developed lymphoceles, significantly lower recurrence rates by fibrin glue injections and lower median treatment costs were observed when compared with the other two surgical modalities. It has also the advantage of an outpatient procedure that can be performed using fluoroscopic guidance, under local anesthesia. However, due to era effect, most of the open and laparoscopic surgical recipients were treated with sirolimus, a well-known antiproliferative immunosuppressive agent, which can promote development of lymphoceles and surgical failure. However, the majority of fibrin glue-treated cases were with tacrolimus-based regimens, but this study, in its nature, is far from giving the answer for decreased number of recurrences with fibrin glue.

Yarkın Kamil Yakupoğlu, MD

\section{Re: Kidney-Failure Risk Projection for the Living Kidney-Donor Candidate}

\section{Grams ME, Sang Y, Levey AS, Matsushita K, Ballew S, Chang AR, Chow EK, Kasiske BL, Kovesdy CP, Nadkarni GN, Shalev V, Segev DL, Coresh J, Lentine KL, Garg AX; Chronic Kidney Disease Prognosis}

Consortium*

${ }^{*}$ Coresh J, Matsushita K, Sang Y, Rebholz CM, Green J, Kirchner HL, Chang A, Garg AX, McArthur E, Kim SJ, Lam NN, Chodick G, Shalev V, Goldshtein I, Ash N, Moser SS, Bottinger EP, Nadkarni GN, Ellis SB, Nadukuru R, Grams M, Segev DL, Muzaale AD, Massie AB, Chow EK, Kasiske B, Lentine KL, Kovesdy CP, Molnar MZ, Coresh J, de Jong PE, Gansevoort RT, Grams M, Hallan S, Kovesdy CP, Levey AS, Matsushita K, Shalev V, Woodward M, Ballew SH, Coresh J, Grams M, Matsushita K, Sang Y, Woodward M

N Engl J Med. 2016;374:411-421. doi: 10.1056/NEJMoa1510491. Epub 2015 Nov 6.

\section{EDITORIAL COMMENT}

The authors have evaluated the risk of progression to end-stage renal disease (ESRD) after kidney donation in 4.933 .314 healthy participants from 7 cohorts and 52.998 living kidney donors. The 15-year observed risk of ESRD after donation was 3.5 to 5.5 times higher in the kidney donors group. The projected 15 -year risk (in the absence of donation) for the average black male donor candidates was $0.21 \%$ and the observed risk (after donation) was $0.96 \%$. The risks among black women were $0.12 \%$ and $0.59 \%$; the risks among white men were $0.07 \%$ and $0.34 \%$, respectively, and the risks among white women were $0.04 \%$ and $0.15 \%$, respectively. Risk projection were higher in the presence of lower estimated glomerular filtration rate (GFR) (adjusted hazard ratio for GFR $<60 \mathrm{ml} / \mathrm{min} / 1.73 \mathrm{~m}{ }^{2}$, $\left.6.61,60-89 \mathrm{ml} / \mathrm{min} / 1,73 \mathrm{~m}^{2}, 1.63\right)$. Other characteristics that were associated with a higher risk of ESRD included noninsulin-dependent diabetes (HR; 3.01 ), higher systolic blood pressure (heart rate (HR) per increase of $20 \mathrm{mmHg}, 1.42$ ), use of antihypertensive medication (HR for the comparison with no use, 1.35), previous smoking (HR for the comparison with never smoking, 1.45), current smoking (HR for the comparison with never smoking, 1.76), and higher urinary albumin-to-creatinine ratio (HR per increase of 10x, 2.94).

The online risk tool developed by the authors can be used to evaluate, counsel, and accept living kidney-donor candidates (www.transplantmodels.com/esrdrisk). 